\title{
Improving Elementary School Teachers' Competence in Composing Thematic Songs: An Action Research
}

\author{
J. Julia ${ }^{1 *}$, Sandie Gunara ${ }^{2}$, Tedi Supriyadi ${ }^{3}$, Egi Agustian ${ }^{4}$, Enjang Yusup Ali ${ }^{5}$, Agus Budiman ${ }^{6}$ \\ 1,3,5Elementary Teacher Education Program, Universitas Pendidikan Indonesia, Bandung, Indonesia \\ ${ }^{4}$ SDN Pakuwangi, Sumedang, Indonesia \\ ${ }^{2,6}$ Faculty of Arts and Design Education, Universitas Pendidikan Indonesia, Bandung, Indonesia
}

\begin{abstract}
The existence of thematic songs in theme books in Elementary Schools appears to be ineffective in supporting the attainment of learning objectives. In addition to the limited number of songs, the lack of appropriate lyrics and materials remains one of the causes. Due to this, the most possible alternative solution is for teachers to compose their own thematic songs. However, elementary school teachers lack the ability in composing thematic songs, hence they need to be given related training. The purpose of this research is to increase elementary school teachers' capacity for creativity and innovation in order to produce thematic songs. The research employed a participatory action research design, involving 55 teachers from 16 districts and cities in Indonesia. The data were collected using survey, observation, and interview. The results showed that these teachers were able to develop their ability to compose thematic songs. Teachers were also able to utilize technology in the composing process. Based on the aforementioned findings, it can be stated that elementary school teachers can improve themselves and innovate effectively with planned and regulated training.
\end{abstract}

Keywords: Composing songs, songwriting technology, Teachers' competence, Thematic songs.

\section{INTRODUCTION}

The 2013 Curriculum is implemented at all school levels in Indonesia, including elementary school. A distinctive feature of the curriculum is the absence of subject names, such as science, social studies, Civics Education, Cultural Arts and Crafts, and Indonesian which are replaced by the term theme. This curriculum requires education in elementary schools to use integrated thematic learning. Thematic learning is a combination of several subjects that are associated to one theme and then delivered to students in a series of materials (Azimah \& Utomo, 2018). The government has facilitated the teachers by providing themed books that teachers can use as a guide for implementing learning. However, based on the analysis results, there are still many shortcomings in the book, one of which is related to thematic songs.

According to the results of a survey conducted to 271 teachers from various regions in Indonesia, it was obtained that out of the 271 surveyed teachers, 199 (73.4\%) of them stated that there were only few thematic songs that corresponded to the learning materials in the theme book. Moreover, out of 271 teachers, $136(50.2 \%)$ of them admitted that the correlation or integration of thematic songs with the learning materials in the theme book seemed forced, and 258 (95.2\%) of them claimed that they needed new thematic songs that were more compatible with the materials. The survey results indicate that the thematic songs included in the theme book do not have a significant impact on learning, particularly music learning. Negligence on this issue can transform into a serious problem that has a negative impact, especially on students' musical development. It can hinder the construction process of students' musical competence (Hernández-Bravo et al., 2016).

One of the most possible alternative solutions to address this problem is by making the teachers compose their own thematic songs. Creating their own allows the melody and song lyrics to be more compatible with the learning materials. Unfortunately, the reality shows that teachers are not yet moving towards that direction. This is due to the teacher's lack of ability and knowledge in composing songs, particularly in melodies and lyrics (Sinaga, 2010). Therefore, training is needed to develop the teachers' competence in composing thematic songs. However, based on the results of a survey conducted in 2020 in Sumedang Regency (West Java Province), the local education authorities (government) rarely initiate training programs to improve teachers' competence in the music field. In fact, in the last two years, there has been no

\section{Corresponding Author e-mail: juli@upi.edu \\ https://orcid.org/0000-0002-0249-0264}

How to cite this article: Julia J, Gunara S, Supriyadi T, Agustian Ali EY, Budiman A (2022). Improving Elementary School Teachers' Competence in Composing Thematic Songs: An Action Research. Pegem Journal of Education and Instruction, Vol. 12, No. 1, 2022, 131-141

Source of support: Nil

Conflict of interest: None.

DOI: 10.47750/pegegog.12.01.12

Received: 19.08.2021

Accepted: 12.11.2021 Publication: 01.01.2022 
training program at all (Julia, Supriyadi, et al., 2020). This condition prompted us to initiate a thematic song training program for elementary school teachers. Therefore, following the training, the teachers will have the ability to compose thematic songs and deliver a solution to the aforementioned problems.

Previous researches have shown that government support for training programs is crucial. Hennessy et al., (2005) conducted a study aimed at increasing the competence and confidence of teachers in teaching music. They were trained by being given 21 training modules. However, the training failed to solve the problem. Based on the results of the interviews, it was revealed that small funds from the government had a significant impact on the training participants.

Another study was also conducted by Utami \& Muhdiyati (2020), which aimed at acknowledging the frequency of songs included in the integrated thematic books of revised 2013 curriculum. The study was conducted by using quantitative content analysis method on 24 thematic books published by the Ministry of Education and Culture in 2017. The results revealed that learning through songs in the early grades gradually decreased in quantity.

A relevant study was also conducted by Sinaga (2010) who investigated teachers' challenges in composing children's songs. The results showed that the teachers found it difficult to write songs and lyrics. They were unable to easily find fitting words to build a song that suited the learning materials. Another difficulty was matching the phrases with the melody, matching syllables with melody and sentences. Other than the melody, the teacher's problem laid in the ability to determine high and low notes, note values, and song notation.

Referring to the results of previous research, there has not been any solution to improve the teacher's ability to make thematic songs and add vocabulary to thematic songs in effective ways. Therefore, this research is believed to provide a novelty to solve the issues of teachers in creating thematic songs according to the needs of their respective schools. Teachers were given a series of critical-reflective actions to compose thematic songs and add vocabulary to thematic songs. They were also equipped with technological literacy supporting the process of making songs so that they have the convenience to create songs.

\section{Teachers' Competence}

Çetin \& Doğan (2018); Johansson et al. 2015; Li et al. (2018) suggest that in 1986, Shulman divided teacher capability into three parts: content knowledge, pedagogical knowledge, and pedagogical content knowledge. Meanwhile, according to Cooper \& McIntyre (1996), Hennessy et al. (2005), Monk \& Osborne (1997), and Osborne \& Collins (2001) expert educator capabilities include insights about knowledge and human behavior; knowledge about the field of learning; the right attitude about oneself, school, peers, and the field of study raised; respectable abilities in teaching methods. From these studies, it can be concluded that the essence of teacher capability is when deep content knowledge meets pedagogical content knowledge. Over time, these two elements improve, be it in teachers' formal education or in their teaching training. However, content becomes a key aspect in these current years (Darling-Hammond \& Bransford, 2007; Epstein, 2018; Grossman et al., 2009; Stronge et al., 2011; Walshaw \& Anthony, 2008), in accordance with Townsend (2011); Augustine \& Wong (2016); Maguraushe (2015); Concina (2015); Rauduvaite \& Wang (2018) who claim that content and method mastery play a serious role in operative coaching, serving as a solid basis for music educators' instructions .Other researchers view capability as a basic characteristic of an individual, including information, abilities, and attitudes connected to the work employed ( Issenberg et al., 2005; Frese et al., 1997; Luthans, 2002; Spencer \& Spencer, 2008). It plays an instrumental role in the success of doing work activities (Kolibáčová, 2014; Siri et al., 2020). In addition, high selfconfidence is a distinctive feature in competent teachers. Achieng'Akuno (2019); Human \& van Niekerk (2014); Njoora (2015) suggest that confidence is a form of motivator. Akuno (2012) also states that good teaching during coaching is something a music educator needs in order to empower him or her to teach confidently.

\section{Thematic Songs}

Song is a form of articulated delivery of messages, consisting of non-verbal elements (e.g. tone, dynamic marks, instruments) and verbal elements (language elements) (Witantina et al., 2020; Yunita et al., 2021). At first, these two elements were inseparable but over the period of time, the delivery of songs developed into several types. There are songs that combine elements of music and language, some do not require musical instruments, and some others do not include the language element. According to Mahmud \& Fat (2010; Mansurdin (2020); Santosa (2019), songs play a significant role in the learning process. From the language perspective, songs will provide language experience in the form of vocabulary. In addition, songs help children reach maturity in terms of developing physical, intelligence, emotional and social aspects of children. Meanwhile, the elements of melody, rhythm, harmony, expression, and song structure, when linked to language competence, can be used as a medium to develop reading and literary skills, especially with regard to problems of intonation, vocalization/articulation, expression/ mimicking, and sentence comprehension.

Meanwhile, thematic learning is a learning program that starts with one particular theme/topic and is subsequently elaborated from various aspects or viewed from various perspectives on subjects that are usually taught in schools 
(Kadir \& Asrohah, 2015). Based on these two explanations, it can be concluded that thematic songs are a form of delivering messages that contain spoken thematic learning material contents consisting of verbal and non-verbal elements.

\section{Research Objectives}

Apart from the various literatures regarding songs, we identify the need for a study that examines competency development in composing thematic songs, because this topic has not been widely studied by other researchers. Therefore, the main objective of this study is to improve the competence of elementary school teachers in composing thematic songs in the 2013 Curriculum learning. It is expected that teachers are able to make thematic songs independently and can add vocals to thematic songs in creating teaching materials for the students. This study seeks to investigate the problem through the following questions: (1) Can elementary school teachers improve their competence in composing thematic songs? (2) Can elementary school teachers use technology in composing thematic songs? (3) Will a series of critical-reflective steps be able to shift the paradigm of elementary school teachers to be more creative in composing thematic songs? Through a series of critical-reflective actions, this research is expected to contribute by leading the elementary school teachers to make thematic songs, thus, that they can provide additional thematic songs to be used as teaching materials for thematic songs in elementary schools.

\section{Method}

\section{Research Design and Collaboration}

This study employs a participatory action research design. Studies with action research design are conducted by collecting information and then improving the ability of research subjects (Creswell, 2002). This design was used because in this study, data were collected in the form of self-reflection questions that served to improve the subjects' understanding of the practice (McTaggart, 1994). This study aims at developing critical steps to improve teachers' understanding. This is in line with Creswell (2002), who suggests that the purpose of action research is to explore practical problems with the aim of developing solutions to these problems. In addition, through action research, teachers are also believed to increase their morale and self-confidence (Jenkins Dr \& Crawford, 2016; Pelton, 2010).

Collaboration is an important element in action research (Creswell, 2002; Jaipal \& Figg, 2011; Leeman et al., 2018; Julia, Hakim et al., 2019). Therefore, collaborators were engaged in this study to meet the requirement. This study was assisted by two colleagues whose duties were to prepare training facilities and infrastructure, manage the participants, and observe the participants during the training.

\section{Subjects and Site of the Study}

This study involved participants from various regions and cities in Indonesia. The site of the study was centered in Sumedang, West Java, which was the city where the researchers resided and worked. Sumedang Regency is divided into three regions based on the level of development, namely urban, transitional and rural. The site of the study is shown in Figure 1. The mode of the study was carried out online through synchronous and asynchronous techniques.

A total of 55 participants took part in this study, comprising $47(85.5 \%)$ women and eight (14.5\%) men. Twelve (21.8\%) of them taught the first grade, three (5.5\%) of them taught the second grade, three ( $5.5 \%)$ of them taught the third grade, five $(9.1 \%)$ of them taught the fourth grade, 18 (32.7\%) of them taught the fifth grade, and 28 (21.8\%) of them taught the sixth grade. A total of 51 (92.7\%) participants taught in public schools and four (7.3\%) taught in private schools, with $44(80 \%)$ of them were civil servants and the remaining $11(20 \%)$ were non-civil servants. Regarding areas of residence, the participants of this

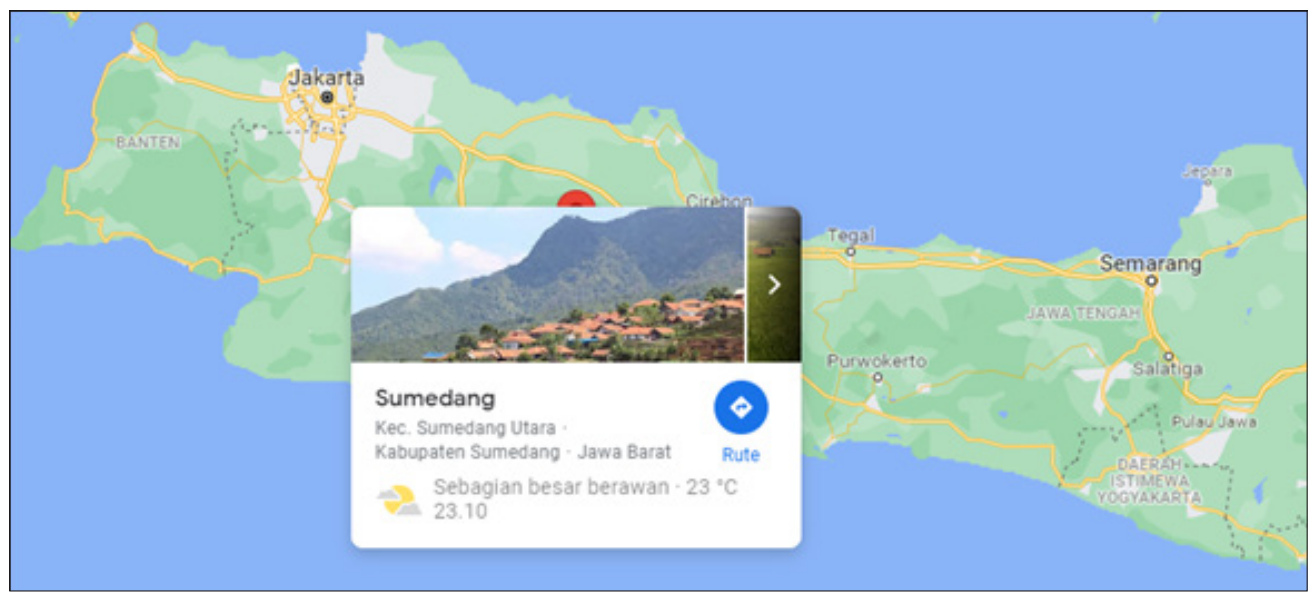

Figure 1: The Site of the Study 
study came from 16 districts and cities. The most participants were from Sumedang by 32 participants, followed by Bekasi by four participants, Cirebon by three participants, Bogor, Jakarta, Central Lampung by two participants each, and West Bandung, Blora, Cianjur, Indramayu, Tasikmalaya, Magelang, Sukabumi, Bengkulu, Cimahi, and Depok by one participant each. Meanwhile, regarding the age of the participants, this training involved five (9.1\%) participants aged between 21-25 years old, 20 (36.4\%) participants between 26-30, 16 (29.1\%) participants aged between $31-35$, five $(9.1 \%)$ participants aged between 36-40, one (1.8\%) participant aged between 41-45, four $(7.3 \%)$ participants aged between $46-50$, and four (7.3\%) participants aged between 50-55.

\section{Procedures of the Study}

This study was conducted in three stages; the first stage was pre-action, followed by the action stage, and ended by the post-action stage. The first stage (pre-action) involved survey activities and initial data analysis. The survey was distributed to participants before the training activities were carried out. Then the second stage (action) involved training and practicing composing thematic songs. At this stage, six critical-reflective steps that aim to improve teacher competence in composing thematic songs were created, namely exploration and motivation, introduction to thematic songs, analysis of thematic books, exploration of creativity in making confirmation thematic songs, revision and evaluation. The last stage (post-action) involved a post-action survey and evaluation. At this stage, after all the training series were completed, participants were directed to fill out an online survey. The survey consisted of several questions in form of open-ended questions, Likert and Gutman scales. This survey aimed at identifying the teachers' knowledge and ability in comprehending the training materials provided as well as to identify their views in regards to competence development in composing thematic songs.

Zoom Meeting was utilized as the main platform in this training. In addition, WhatsApp groups were also employed as a supporting tool used to deliver information related to training. Zoom meeting was selected as the main platform for the training due to the situation and conditions in Indonesia, especially the Sumedang Regency which was impacted by the COVID-19 pandemic hence it was prohibited to hold any

Table 1: Research Phases and Activities

\begin{tabular}{ll}
\hline Phases & Activities \\
\hline Pre-Action & $\begin{array}{l}\text { Analysis of the needs and initial conditions of the } \\
\text { participants }\end{array}$ \\
Action & $\begin{array}{l}\text { Planning, implementation, observation and } \\
\text { reflection (continuous improvement cycle) }\end{array}$ \\
Post-Action & Evaluation and analysis of action results \\
\hline
\end{tabular}

forms of activity that bring a lot of people together. Meanwhile, the WhatsApp group was used because it was one of the communication media that was very familiar among the participants. In addition to these two applications, this study also utilized Google Forms which was used as a survey tool. This tool was used based on several considerations: it is easy to use, it is familiar among educators, it has complete features as a survey tool, it eases the work of researchers, it collects accurate data, and it does not require special skills to use it (Laskowski \& Laskowski, 2016).

An overview of the procedures in this action research which contain three main stages and the cyclical principle (continuous improvement) is presented in Table 1.

\section{Results}

A planned and structured process was carried out in this study so as to produce critical and evaluative thinking in relation to improving the ability of elementary school teachers in composing thematic songs. This process involves data collection, pre-action analysis, six-stage action, and post-action analysis. The following is a detailed elaboration of the three overall action processes.

\section{Pre-action Analysis}

Pre-action surveys were distributed to participants prior to the training activities. The survey aimed at identifying their initial knowledge in composing thematic songs as well as their views on the existing thematic songs. Table 2 describes the results of participants' responses to several questions and statements related to the existence of thematic songs. Based on the table, it was revealed that out of 55 participants, 45 (82\%) of them strongly agreed and 10 (18\%) agreed that thematic songs were imperative in learning the 2013 Curriculum. Following a further investigation, one participant explained that songs and art played an important role in motivating or stimulating interest and readiness in learning. Even songs could help children memorize and build their knowledge. Other participants argued that thematic songs were very essential in learning because they could increase students' motivation and enthusiasm for learning. There were also participants who believed that thematic song served as a bridge between subjects constituting a comprehensive thematic learning. The three explanations above confirm that thematic songs have a fundamental role in the learning process, especially those related to students' learning readiness and motivation.

Furthermore, in the second statement that was "there are only a few thematic songs that suit the learning materials in the theme book", 13 (24\%) participants strongly agreed, 30 (55\%) agreed, 8 (14\%) disagreed, and 4 (7\%) people disagreed. Meanwhile, in the statement "the correlation or integration of thematic songs with the learning materials in the theme book seems to be forced", out of 55 participants, nine (16\%) 
Table 2: Participants' Knowledge and Views on the Existence of Thematic Songs

\begin{tabular}{|c|c|c|c|c|c|}
\hline Statements & Strongly Disagree & Disagree & Slightly Disagree & Agree & Strongly Agree \\
\hline $\begin{array}{l}\text { Thematic songs are essential in learning using the } 2013 \\
\text { Curriculum. }\end{array}$ & 0 & 0 & 0 & 10 & 45 \\
\hline $\begin{array}{l}\text { There are only a few thematic songs that suit the learning } \\
\text { materials in the theme book. }\end{array}$ & 0 & 4 & 8 & 30 & 13 \\
\hline $\begin{array}{l}\text { The correlation or integration of thematic songs with the } \\
\text { learning materials in the theme book seems to be forced. }\end{array}$ & 1 & 2 & 20 & 23 & 9 \\
\hline $\begin{array}{l}\text { New thematic songs that are more suitable with the learning } \\
\text { materials are needed. }\end{array}$ & 0 & 0 & 1 & 15 & 39 \\
\hline
\end{tabular}

Action: Composing Thematic Songs Training for Elementary School Teachers

strongly agreed, 23 (42\%) agreed, 20 (26\%) disagreed, 2 (4\%) disagreed, and only 1 (2\%) strongly disagreed. As for the statement "new thematic songs that are more in line with the learning materials are needed", out of 55 participants, 39 (71\%) strongly agreed, 15 (27\%) agreed, and only 1 (2\%) disagreed.

According to the answers to some of the statements above, a conclusion can be drawn that the existence of thematic songs in the 2013 Curriculum theme book is rather ineffective in supporting the process of achieving the learning objectives. This is due to the fact that the existing thematic songs are not in compatible with the content of the learning materials. In addition, the integration of the song with the material also seems forced. Therefore, new thematic songs that are more suitable and integrated with the learning materials are needed.

Referring to urgent aspects to be acknowledged and mastered by elementary school teachers, as well as according to the results of the pre-action survey, the critical action resulted in six main steps. Throughout the action stage, several measures were done in response to the participants' difficulties, which pleaded to be handled in accordance with their requirements.. Simultaneously, observations and reflections were made. The following are six critical action steps to improve the ability of elementary school teachers to compose thematic songs.

\section{Step 1: Exploration and Motivation}

The results of the pre-action survey shows that all participants agreed that thematic songs were essential in learning using the 2013 Curriculum. According to Sinaga (2010) songs play a significant role in the learning process. From the language perspective, songs will provide children with language experience in the form of vocabulary. In addition, songs help children reach maturity in terms of developing physical, intelligence, emotional and social aspects of children. Meanwhile, the elements of melody, rhythm, harmony, expression, and song structure when linked to language competence can be used as a medium to develop reading and literary skills, especially with regard to problems of intonation, vocalization/articulation, expression/mimicking, and sentence comprehension. However, the existing thematic songs cannot be used optimally. In addition to the small number, the lack of cohesiveness and suitability with the materials is one of the factors. Therefore, at this stage, the trainer explores the participants' the knowledge and views, particularly exploring what they can do to provide a solution to the problem. This activity was conducted through an open question and answer session with all participants.

From this session, some information was obtained. All participants understood the conditions of the existing problems. They understood that the thematic songs included in the 2013 Curriculum theme book was far from adequate. This was experienced by the first-grade teacher, as the songs in the theme book were similar, only the lyrics were changed. In addition, the participants also stated that the correlation between song lyrics and the materials appeared to be forced. This was proven by showing several thematic songs in the theme book. In addition, from the question and answer session, another problem was also found. It was the inability of almost all participants to read song notation, hence, it was very challenging for them to teach new songs to students. Meanwhile, the theme book only provided the music without an example of the song.

With the information above, the trainer gave some motivation that this condition should not be allowed to persist. If it does, it will bring about a negative impact, particularly on students. They will not benefit from optimal learning, thus a solution to this problem is compulsory. One of them is that teachers must be able to compose their own thematic songs.

\section{Step 2: Introduction to Thematic Songs}

At this stage, examples of thematic songs were shown to the participants. The song was the work of the trainer himself. The participants were informed about the ideal thematic song, starting from the lyrics which should be easy to understand and correlate with the learning materials, and the difficulty level of the melody should adjust the grade level. Moreover, the participants were also given the opportunity to sing the song together. 


\section{Step 3: Thematic Song Composing Technique}

At this stage, the participants were taught about thematic songcomposing techniques from lyrics, melodies to scores. Lyrics should be written as simple as possible so that they are easily memorized by the students. Meanwhile, in terms of melodies, especially for those who are composing for the first time, they can start with the melodies of existing songs with a change in the beginning or in the final tone. Furthermore, for making sheet music, application can be used.

Also at this stage, the trainer also gave the participants the opportunity to ask questions related to the technique of composing thematic songs. Some of the participants stated that they were not competent in singing, as a result they could not compose the melody of the song. Others stated that they could not read the song notations, let alone make sheet music.

Addressing these challenges, the trainer offered a number of solutions. Participants who were not competent in singing could collaborate with other participants, so that they could compose songs without having to sing, for example contributing to the lyrics or the sheet music. Meanwhile, for participants who were unable to read sheet music, they could use application assistance. The application recommended by the trainer was MuseScore.

\section{Step 4: Exploration of Creativity in Thematic Song Composing}

Following the trainer's explanation on the techniques of composing thematic songs, all participants were instructed to make their own thematic songs. They were allowed to collaborate with other participants or work individually. This activity was carried out outside the zoom meeting. However, participants still had to communicate with the trainer and other participants through the WhatsApp group. In this group, the participants discussed the techniques of composing songs, starting from determining the grade levels, the materials, to basic competencies. At this stage the committee and trainer were always ready to assist participants who were having difficulties. Also at this stage, the creativity of the participants was needed. Therefore, the trainer always provided a stimulus to stimulate their creativity.

\section{Step 5: Revision}

Revision activities were carried out in the following meeting. After the participants were given one week to compose a song, the progress of the song was reported to the trainer. Each participant was given the opportunity to report their progress. Out of 55 participants, some had only finished the lyrics, some had finished with the melodies and some had even finished with the sheet music.

At this stage, many findings emerged, particularly from the participants, one of which was that some participants were able to compose songs very well. There were also participants who were creative to overcome their limitations by finding applications that could convert voices into sheet music. This discovery was very useful because the application made the sheet music easier. The name of the application was Soundcore.

Following the participants' reports of their progress in composing the song, the trainer gave input to all participants in accordance with their respective shortcomings. The input from the trainer included changing the basic tone to be higher for those whose tones were too low or vice versa, perfecting lyrics that were not in accordance with the materials, and simplifying lyrics that were too complex so that they would be easy to memorize by the students. An example of the participants' work is displayed in Figure 2.

\section{Step 6: Evaluation of Thematic Song Composing Results}

The last face-to-face activity was conducted at this stage. Several representatives of the participants tried to present their work. The activity continued with reflection through questions and statements directed to participants via Google

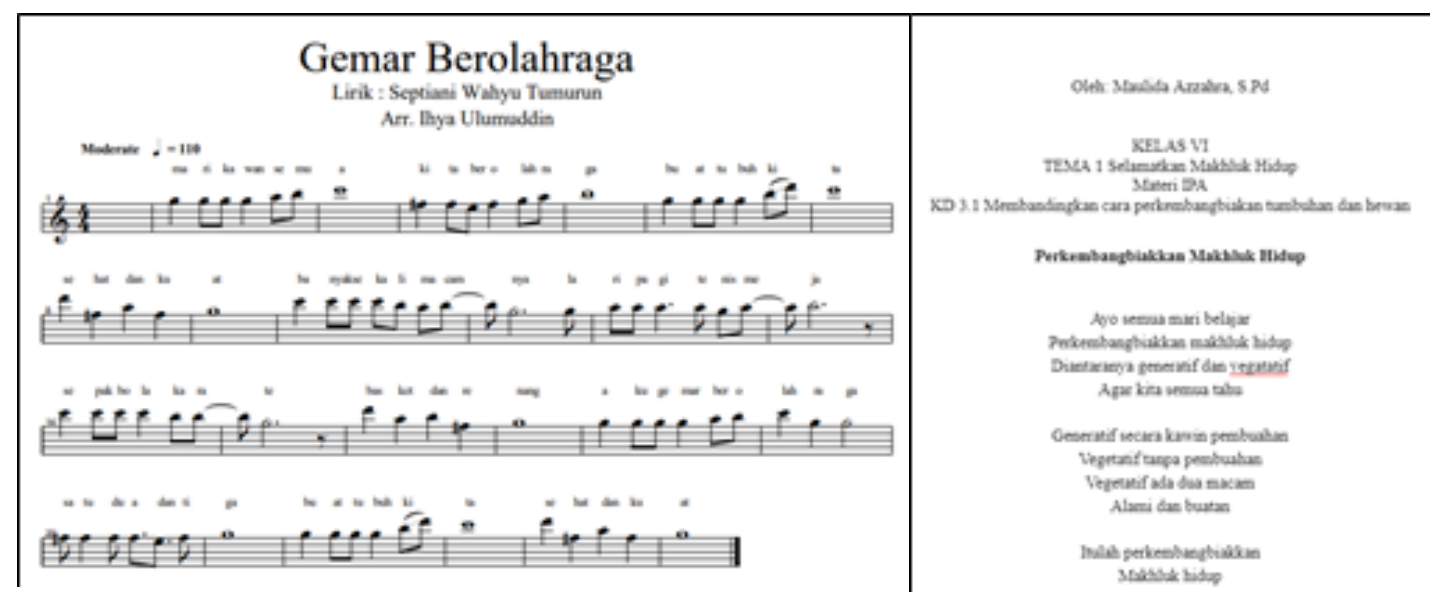

Figure 2: An Example of Sheet Music and Song Lyrics by Participants 
Form. These statements and questions also served as survey tools to collect post-activity information in this study. One of the participants gave his testimony "I really want to be able to compose other thematic songs so that they can help students learn something easier as well as enriching the thematic song collection. Before this I also liked to compose songs but the melody was taken from existing popular child songs. After this activity, I am also motivated to compose a thematic song that is truly an original work by myself, both the lyrics and the melodies." Another participant said, "After the explanation on how to compose songs by the trainer, I think that composing thematic songs is not as difficult as I imagined. Thus, it makes me more motivated to compose songs for learning." These two testimonies show that this training activity left a profound impression on the participants so that they were motivated to continue to improve their competence.

In addition to filling out the post-action survey, participants were also directed to submit assignments by uploading them to Google Drive for further evaluation. Based on the results of the assessment, it was revealed that out of 55 participants, as many as $15(27.3 \%)$ of them composed songs for grade I, 4 (7.3\%) participants for grade II, 2 (3.6\%) participants for grade III, 8 (14.5\%) participants for grade IV, 14 (25.4\%) participants for grade V, and 12 (21.8\%) participants for grade VI. Meanwhile, based on the subjects, $52(94.5 \%)$ participants composed song lyrics on thematic subjects, two (3.6\%) participants on mathematics and one (1.8\%) participant on religious subject.

Based on the results of submitted assignments, 34 melodies and 46 song lyrics were collected, both individually and collaboratively. After the assessment, it was obtained that from the 34 melodies collected, as many as $9(26.5 \%)$ melodies were categorized as excellent, 7 (20.6\%) were very good, 9 (26.5\%) were good, $4(11.8 \%)$ were sufficient, and $4(11.8 \%)$ were poor. Meanwhile, out of the 46 lyrics collected, 12 (26.1\%) lyrics were categorized excellent, 13 (28.3\%) were very good, 12 (26.1\%) were good, 8 (17.4\%) were sufficient, and $2(4,3 \%)$ were poor.

\section{Discussion and Conclusions}

\section{Post-Action}

In the last meeting, as a closing activity, all participants were given a post-action survey. The survey aimed at determining the extent of the participants' abilities and knowledge following training. Based on the survey results, most of the participants, as many as $45(80.4 \%)$ strongly agreed that thematic songs played an essential role in learning, nine (16.1\%) agreed and only two (3.6\%) disagreed. Moreover, 49 (87.5\%) participants strongly agreed that thematic songs made it easier for students to understand the learning materials, five $(8.9 \%)$ agreed, one (1.8\%) disagreed, and another one (1.8\%) strongly disagreed. After further exploration, some participants stated that songs could stimulate children's intellectuality, stimulate the readiness of the brain to absorb learning in a fun way. Others argued that thematic songs would spark students' interest, attention, and enthusiasm to be more active in participating in learning. Accordingly, with thematic songs, students will find it easier and faster to grasp the information delivered by the teacher. Additionally, thematic songs can also shape characters, help students express themselves (happiness/joy) and make it easier for students to learn language and process it. This is in line with the view of Roffiq et al. (2017) who suggest that music can transform the learning environment to be fun so that students are enthusiastic to learn. Music can trigger great connections among areas in the brain that are responsible for emotion and memory. Using music as a tool to optimize human potential is a very meaningful endeavor. Music has the ability to inspire and encourage students to engage in activities that will assist them in achieving social, linguistic, and motor function objectives.

During the training process, making sheet music was the most difficult part that the participants experienced in composing thematic songs. This was acknowledged from the results of the survey which shows $44(78.6 \%)$ participants found it difficult to make sheet music. This condition is supported by data that $39(69.6 \%)$ participants were incapable of reading sheet music. This condition illustrated the lack of music competence of elementary school teachers (Julia et al., 2019). Following a further exploration to the core of the problem, it appears that the participants did not have a theoretical basis or knowledge about making sheet music. This affected the learning process in the classroom as the teacher found it difficult to sing the thematic songs in the theme book due to their inability to read the sheet music. Based on the post-action results, 50 (96.5\%) participants agreed that one solution to the problem is to include a link that directs to YouTube. Therefore, even if the teachers cannot read the sheet music, they can see how to sing the song via YouTube. This is in line with the opinion of Nacak et al. (2020) who suggest that YouTube can help the learning process. Through this media, teachers can see and learn how to sing a song as many times as they wish. Meanwhile, to overcome the difficulties in composing sheet music, 21 (37.5\%) participants in this training utilized software assistance. The software used were MuseScore and ScoreCloud. MuseScore and ScoreCloud are applications that can be used to compose songs. Rantina et al. (2019) in their study explain that the development of children's songs using MuseScore application in developing aspects of early childhood development is valid, practical and has the potential to be used by teachers in the learning process employing the singing method.

In addition to the sheet music, the most difficult part of composing a song is the melody. This information was obtained based on the survey results, through the statement "I have no significant difficulty in composing a melody," five 
(8.9\%) participants strongly disagreed, 17 (30.4\%) participants disagreed, $22(39,3 \%)$ participants slightly disagreed, 11 (19.6\%) participants agreed, and one (1.8\%) participant strongly agreed. However, these difficulties did not hinder the participants from being able to compose songs. Various ways were done to find solutions to these problems, one of which was by using software. As many as 18 (32.7\%) participants utilized software to compose songs. The software used were ScoreCloud, MuseScore, Fruity Loops, Nuendo, Harmony, and Hookpad. The integration of technology into song composing can overcome the obstacles encountered, particularly during the song composing process (Ertmer, 1999; Julia, Iswara, et al., 2020). An example of the use of software in composing a song is displayed in Figure 3. This confirms that elementary school teachers can use technology (Julia, Afrianti et al., 2020) in making thematic songs. Hence, the second research question is "Can elementary school teachers use technology for teaching music?" was proven attainable.

After participating in a series of song-composing training activities, most of the participants realized that composing thematic songs was not as difficult as imagined. This information was obtained based on the results of the postsurvey with the statement "After attending this training I realized that composing thematic songs is not as difficult and as complicated as I imagined". In response to this statement, 2 (3.6\%) participants disagreed, 25 (44.6\%) participants slightly disagreed, 19 (33.9\%) participants agreed and 10 (17.9\%) participants strongly agreed. After a further investigation, one participant said "actually I still don't understand but I got the hint of composing songs like that, so in the future I can make songs using melodies and sheet music". There were also participants who stated "After being given an explanation on how to compose songs by the trainer, I think that making thematic songs is not as difficult as I imagined". Another participant said "Composing songs is very fun. With the application, making notation to compose songs is easier". While another other participant said "it is not too difficult anymore because I have received enough knowledge from the trainer. We just need to improve our creativity in practicing and producing songs constantly." For this reason, 54 (98.2\%) participants strongly agreed that elementary school teachers need to be given continuous training in composing thematic songs. Other than that, all participants also agreed that activities like these should be regularly carried out because in addition to improving the teachers' competence, it is also a platform for teachers who have the potential to develop their interests and talents, particularly in composing songs. Thus, the answer to third research question "Will a series of critical-reflective steps be able to change the paradigm of elementary school teachers to be more creative in creating thematic songs?" is "yes".

After completing the training, out of 55 participants, 47 (85.5\%) of them planned to compose their own thematic songs. This proves that this training activity is quite effective in increasing the teachers' competence, particularly in composing thematic songs. This answers the first research question, that elementary school teachers can improve their competence in composing thematic songs.

A number of achievements in this study serve as objects of consideration for us to continue to conduct training activities for teachers, particularly those related to improving competence in the field of music. Therefore, it can be concluded that the third research question is answered, namely the critical-reflective steps taken in the training can change the paradigm of elementary school teachers to be more creative in teaching music.

In conclusion, based on the results of this study, with reference to the questions posed at the beginning, namely: (1) Can elementary school teachers improve their competence in composing thematic songs? They proved that the majority of them were able to improve their competence in composing songs; (2) Can elementary school teachers use technology in composing thematic songs? They proved that the majority of them were able to use technology to help compose songs; Elementary school teachers indicated that the majority of them were able to use technology to help compose songs; (3) Will a

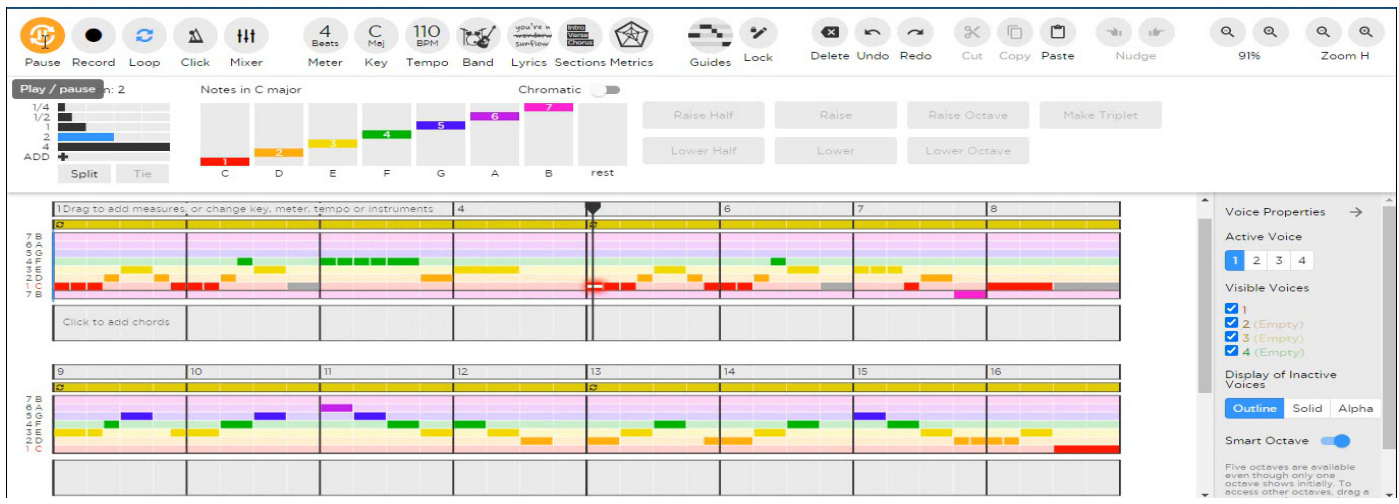

Figure 3: Display of Hookpad Software 
series of critical-reflective steps be able to shift the paradigm of elementary school teachers to be more creative in composing thematic songs? A series of critical-reflective steps can shift the paradigm of elementary school teachers to be more creative in composing thematic songs. Therefore, it can be identified that the six series of critical-reflective actions have contributed to make the teachers more creative and understand the process of making thematic songs, so that the vocabulary of thematic songs as teaching materials can increase and continue to be developed according to the needs of the teachers. Teachers' technological literacy is also increasing, especially to support the process of making thematic songs. The limitation of this study is that it has not been able to reach the training process so that teachers can make song accompaniments from the songs that they compose completely and independently. Teachers are still tied to collaborative creation. Therefore, further research is required to provide actions, hence, the elementary school teachers can understand and be skilled in making song accompaniments independently.

\section{Acknowledgment}

We would like to extent our gratitude to Institute of Research and Community Service (LPPM, Lembaga Penelitian dan Pengabdian kepada Masyarkat) of Universitas Pendidikan Indonesia for funding this study, with the letter of agreement number 710/UN40.D/PM.01.01/2021. We would also thank the teachers and collaboration partners who have assisted in the implementation of this activity.

\section{References}

Augustine, C., \& Wong, C. (2016). Music Teaching Readiness among Non-Specialised Music Teachers in Government Preschools. Malaysian Journal of Music, 5(2), 54-69. http://ojs.upsi.edu. my/index.php/MJM/article/view/821.

Azimah, N. A., \& Utomo, U. U. (2018). Kreativitas Guru Dalam Menggunakan Lagu-Lagu Pada Pembelajaran Tematik Di Sekolah Dasar [Teacher Creativity in Using Songs in Thematic Learning in Elementary Schools]. Jurnal Seni Musik, 7(1), 25-33. https://journal.unnes.ac.id/sju/index.php/jsm/article/ view/24335.

Barry Issenberg, S., Mcgaghie, W. C., Petrusa, E. R., Lee Gordon, D., \& Scalese, R. J. (2005). Features and uses of high-fidelity medical simulations that lead to effective learning: a BEME systematic review. Medical Teacher, 27(1), 10-28. https://doi. org/10.1080/01421590500046924.

Çetin, A., \& Doğan, A. (2018). Bılım ve sanat merkezlerınde görev yapan matematığk öğretmenlerınin karşılaştıkları sorunlar [Problems faced by mathematics teachers working in science and art centers]. Ankara Üniversitesi Eğitim Bilimleri Fakültesi Özel Ĕ̆itim Dergisi, 19(4), 615-641. https://doi.org/10.21565/ ozelegitimdergisi.370355.

Concina, E. (2015). Music Education and Effective Teaching: Perspectives from a Critical. Literacy Information and Computer Education Journal (LICEJ), 6(2), 1892-1895. https:// infonomics-society.org/wp-content/uploads/licej/published-
papers/volume-6-2015/Music-Education-and-EffectiveTeaching.pdf.

Cooper, P., \& McIntyre, D. (1996). Effective teaching and learning: Teachers' and students' perspectives. McGraw-Hill Education (UK).

Creswell, J. W. (2002). Educational research: Planning, conducting, and evaluating quantitative. Prentice Hall Upper Saddle River, NJ.

Darling-Hammond, L., \& Bransford, J. (2007). Preparing teachers for a changing world: What teachers should learn and be able to do. John Wiley \& Sons.

Dhiu, K. D., \& Laksana, D. N. L. (2021). Child Development Aspects in Early Children Education Curriculum. Journal of Education Technology, 5(1), 1-7. https://ejournal.undiksha.ac.id/index. $\mathrm{php/JET/article/view/30764.}$

Epstein, J. L. (2018). School, family, and community partnerships: Preparing educators and improving schools. Routledge.

Ertmer, P. A. (1999). Addressing first- and second-order barriers to change: Strategies for technology integration. Educational Technology Research and Development, 47(4), 47-61. https:// doi.org/10.1007/BF02299597.

Frese, M., Fay, D., Hilburger, T., Leng, K., \& Tag, A. (1997). The concept of personal initiative: Operationalization, reliability and validity in two German samples. Journal of Occupational and Organizational Psychology, 70(2), 139-161. https://doi. org/10.1111/j.2044-8325.1997.tb00639.x.

Gabrielsen, I. L., Blikstad-Balas, M., \& Tengberg, M. (2019). The role of literature in the classroom: How and for what purposes do teachers in lower secondary school use literary texts? L1-Educational Studies in Language and Literature, 19, 1-32. https://doi.org/10.17239/11esll-2019.19.01.13

Grossman, P., Hammerness, K., \& McDonald, M. (2009). Redefining teaching, re-imagining teacher education. Teachers and Teaching: Theory and Practice, 15(2), 273-289. https://doi. org/10.1080/13540600902875340.

Hennessy, S., Ruthven, K., \& Brindley, S. U. E. (2005). Teacher perspectives on integrating ICT into subject teaching: commitment, constraints, caution, and change. Journal of Curriculum Studies, 37(2), 155-192. https://doi.org/http:// dx.doi.org/10.1080/0022027032000276961

Hernández-Bravo, J. R., Cardona-Moltó, M. C., \& Hernández-Bravo, J. A. (2016). The effects of an individualised ICT-based music education programme on primary school students' musical competence and grades. Music Education Research, 18(2), 176-194. https://doi.org/10.1080/14613808.2015.1049255.

Jaipal, K., \& Figg, C. (2011). Collaborative action research approaches promoting professional development for elementary school teachers. Educational Action Research, 19(1), 59-72. https:// doi.org/10.1080/09650792.2011.547688.

Zahra Kalantarnia; Ahmad Shahvarani semnani; Mohammad Hassan Behzadi; Mohsen Rostamy MalKhalifeh; Mohammad Reza Mardanbeigi. "The Impact of Bybee and Synectics Models on Creativity, Creative Problem-solving, and Students' Performance in Geometry". Journal for Educators, Teachers and Trainers, 11, 1, 2020, 68-78. doi: 10.47750/jett.2020.11.01.007

Jenkins Dr, L. E., \& Crawford, R. (2016). The impact of blended learning and team teaching in tertiary pre-service music education classes. Journal of University Teaching \& Learning Practice, 13(3), 1-23. https://ro.uow.edu.au/jutlp/vol13/iss3/5. 
Johansson, S., Myrberg, E., \& Rosén, M. (2015). Formal Teacher Competence and its Effect on Pupil Reading Achievement. Scandinavian Journal of Educational Research, 59(5), 564-582. https://doi.org/10.1080/00313831.2014.965787.

Julia, J., Afrianti, N., Ahmed Soomro, K., Supriyadi, T., Dolifah, D., Isrokatun, I., ... \& Ningrum, D. (2020). Flipped classroom educational model (2010-2019): A bibliometric study. European Journal of Educational Research, 9(4), 1377-1392. https://doi. org/ 10.12973/eu-jer.9.4.1377.

Julia, J., Hakim, A., \& Fadlilah, A. (2019). Shifting Primary School Teachers' Understanding of Songs Teaching Methods: An Action Research Study in Indonesia. International Journal of Education and Practice, 7(3), 158-167. https://doi. org/10.18488/journal.61.2019.73.158.167.

Julia, J., Iswara, P. D., Gunara, S., Yildiz, Y. M., \& Agustian, E. (2020). Developing Elementary School Teacher Competence in Making Music Learning Media Using Scratch Application: An Action Research. Mimbar Sekolah Dasar, 7(3), 362-385. https://doi. org/10.17509/mimbar-sd.v7i3.29100.

Julia, J., Iswara, P. D., \& Supriyadi, T. (2019). Redesigning and Implementing Traditional Musical Instrument in Integrated Technology Classroom. International Journal of Emerging Technologies in Learning, 14(10). https://doi.org/10.3991/ijet. v14i10.10197

Julia, J., Supriyadi, T., \& Iswara, P. D. (2020). Training the nonspecialist music teacher: Insights from an Indonesian action research study. Universal Journal of Educational Research, 8(2), 547-558. https://doi.org/10.13189/ujer.2020.080226

Kadir, A., \& Asrohah, H. (2015). Pembelajaran tematik [Thematic learning]. Raja Grafindo Persada.

Kolibáčová, G. (2014). The relationship between competency and performance. Acta Universitatis Agriculturae et Silviculturae Mendelianae Brunensis, 62(6), 1315-1327. http://dx.doi. org/10.11118/actaun201462061315.

Laskowski, L., \& Laskowski, L. (2016). Google Forms and Sheets for library gate counts Google Forms and Sheets for library gate counts. Journal of Access Services, 13(3), 151-158. https://doi. org/10.1080/15367967.2016.1184577.

Leeman, Y., van Koeven, E., \& Schaafsma, F. (2018). Inter-professional collaboration in action research. Educational Action Research, 26(1), 9-24. https://doi.org/10.1080/09650792.2017.1301827.

Li, H., Pang, H., \& Hu, Z. (2018). Chinese language teacher competency: A literature review for a study series. Chinese Language Teaching Methodology and Technology, 1(4), 59-67. https://engagedscholarship.csuohio.edu/cltmt/vol1/iss4/7/.

Luthans, F. (2002). The need for and meaning of positive organizational behavior. Journal of Organizational Behavior, 23(6), 695-706. https://doi.org/10.1002/job.165.

Maguraushe, W. (2015). Insights into the zimbabwe integrated national teacher education course: graduates'music teaching competence. Muziki, 12(1), 86-102. https://doi.org/10.1080/1 8125980.2015 .1031452 .

Mahmud, A. T., \& Fat, B. (1994). Musik di Sekolah Kami: Belajar Seni Musik Aktif dan Kreatif untuk Sekolah Dasar Kelas 3 [Music in Our School: Active and Creative Music Learning for Grade 3 Elementary School]. Balai Pustaka.

Mansurdin, S. S. (2020). Pembudayaan Literasi Seni Di SD [Cultivating Art Literacy in Elementary School]. Deepublish.
McTaggart, R. (1994). Participatory action research: Issues in theory and practice. Educational Action Research, 2(3), 313-337. https://doi.org/10.1080/0965079940020302.

Monk, M., \& Osborne, J. (1997). Placing the history and philosophy of science on the curriculum: A model for the development of pedagogy. Science Education, 81(4), 405-424. https://doi. org/10.1002/(SICI)1098-237X(199707)81:4\%3C405::AIDSCE3\%3E3.0.CO;2-G.

Utami, I. I. S., \& Muhdiyati, I. (2020). Distribusi Pembelajaran melalui Lagu pada Buku Tematik Kelas Rendah Sekolah [Distribution of Learning through Songs in Low School Thematic Books]. Jurnal Perseda: Jurnal Pendidikan Guru Sekolah Dasar, 3(2), 110-114.https://jurnal.ummi.ac.id/index.php/perseda/article/ view/955.

Nacak, A., Bağlama, B., \& Demir, B. (2020). Teacher candidate views on the use of youtube for educational purposes. Online Journal of Communication and Media Technologies, 10(2), e202003. https://doi.org/10.29333/ojcmt/7827.

Noel, F. R., Lapian, S. J., \& Pandowo, M. (2017). The affect of work discipline and competence on employee performance (Case Study at Balai Kesehatan Mata Masyarakat Sulawesi Utara). Jurnal EMBA: Jurnal Riset Ekonomi, Manajemen, Bisnis Dan Akuntansi, 5(3), 3528- 3537. https://ejournal.unsrat.ac.id/index. php/emba/article/view/17613.

Osborne, J., \& Collins, S. (2001). Pupils' views of the role and value of the science curriculum: a focus-group study. International Journal of Science Education, 23(5), 441-467. https://doi. org/10.1080/09500690010006518.

Pelton, R. P. (2010). Action research for teacher candidates: Using classroom data to enhance instruction. R\&L Education.

Rantina, M., Hasmalena, H., \& Yosef, Y. (2019). Pengembangan Lagu Berbasis Aplikasi Musescore dalam Pengembangan Aspek Perkembangan Anak Usia Dini [Musescore Application-Based Song Development in the Development of Early Childhood Development Aspects]. Jurnal Obsesi : Jurnal Pendidikan Anak Usia Dini, 4(1), 438. https://doi.org/10.31004/obsesi.v4i1.351.

Rauduvaite, A., \& Wang, L. (2018). The analysis of content of bachelor study programme of music teacher training in Lithuania: attitude of foreign and Lithuanian students. Pedagogika, 132(4), 197-210. https://www.ceeol.com/search/articledetail?id=771923.

Roffiq, A., Qiram, I., \& Rubiono, G. (2017). Media musik dan lagu pada proses pembelajaran [Media music and songs in the learning process]. JPDI (Jurnal Pendidikan Dasar Indonesia), 2(2), 35-40. https://doi.org/10.26737/jpdi.v2i2.330.

Santosa, D. (2019). Urgensi Pembelajaran Musik Bagi Anak Usia Dini [The Urgency of Music Learning for Early Childhood]. Jurnal Ikip Veteran, 26(1), 78-88. http://e-journal.ivet.ac.id/index.php/ pawiyatan/article/view/877.

Sinaga, Syarul. (2010). Pemanfaatan Dan Pengembangan Lagu AnakAnak Dalam Pembelajaran Tematik Pada Pendidikan Anak Usia Dini / Tk [Utilization and Development of Children's Songs in Thematic Learning in Early Childhood Education / Kindergarten]. Harmonia Journal of Arts Research and Education, 10(1), 1-15. https://journal.unnes.ac.id/nju/index. php/harmonia/article/view/55.

Siri, A., Supartha, I. W. G., Sukaatmadja, I. P. G., \& Rahyuda, A. G. (2020). Does teacher competence and commitment improve 
teacher's professionalism. Cogent Business \& Management, 7(1), 1781993. https://doi.org/10.1080/23311975.2020.1781993.

Spencer, L. M., \& Spencer, P. S. M. (2008). Competence at Work models for superior performance. John Wiley \& Sons.

Stronge, J. H., Ward, T. J., \& Grant, L. W. (2011). What makes good teachers good? A cross-case analysis of the connection between teacher effectiveness and student achievement. Journal of Teacher Education, 62(4), 339-355. https://doi. org/10.1177\%2F0022487111404241.

Townsend, A. S. (2011). Introduction to effective music teaching: Artistry and attitude. Rowman \& Littlefield.

Walshaw, M., \& Anthony, G. (2008). The teacher's role in classroom discourse: A review of recent research into mathematics classrooms. Review of Educational Research, 78(3), 516-551. https://doi.org/10.3102\%2F0034654308320292.
Witantina, A., Budyartati, S., \& Tryanasari, D. (2020). Implementasi pembelajaran lagu nasional pada pembelajaran SBDP di sekolah dasar [Implementation of learning the national song in SBDP learning in elementary schools]. Prosiding Konferensi Ilmiah Dasar, 2, 117-121. http://prosiding.unipma.ac.id/index. php/KID.

Yunita, A. T., Prasetiyo, A., \& Astanta, A. T. A. (2021). Implementasi Materi Musik Berdasarkan Kurikulum Tematik 2013 Sekolah Dasar di Kecamatan Sewon Bantul Yogyakarta [Implementation of Music Materials Based on the 2013 Elementary School Thematic Curriculum in Sewon District, Bantul Yogyakarta]. PROMUSIKA: Jurnal Pengkajian, Penyajian, Dan Penciptaan Musik, 9(1), 39-50. https:// journal.isi.ac.id/index.php/promusika/article/view 15774 . 